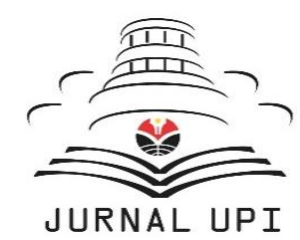

INDONESIAN JOURNAL OF APPLIED LINGUISTICS

Vol. 10 No. 1, May 2020. pp. 84-94

Available online at:

https://ejournal.upi.edu/index.php/IJAL/article/view/24992

https://doi.org/10.17509/ijal.v10i1.24992

\title{
Critical Literacy Approach in the teaching of literary appreciation using Indonesian short stories
}

\author{
Halimah*, Sumiyadi, Yeti Mulyati, and Vismaia S. Damaianti \\ Department of Indonesian Education, Faculty of Language and Literature Education, Universitas Pendidikan \\ Indonesia, Jl. Dr. Setiabudhi 229, Bandung, West Java, Indonesia
}

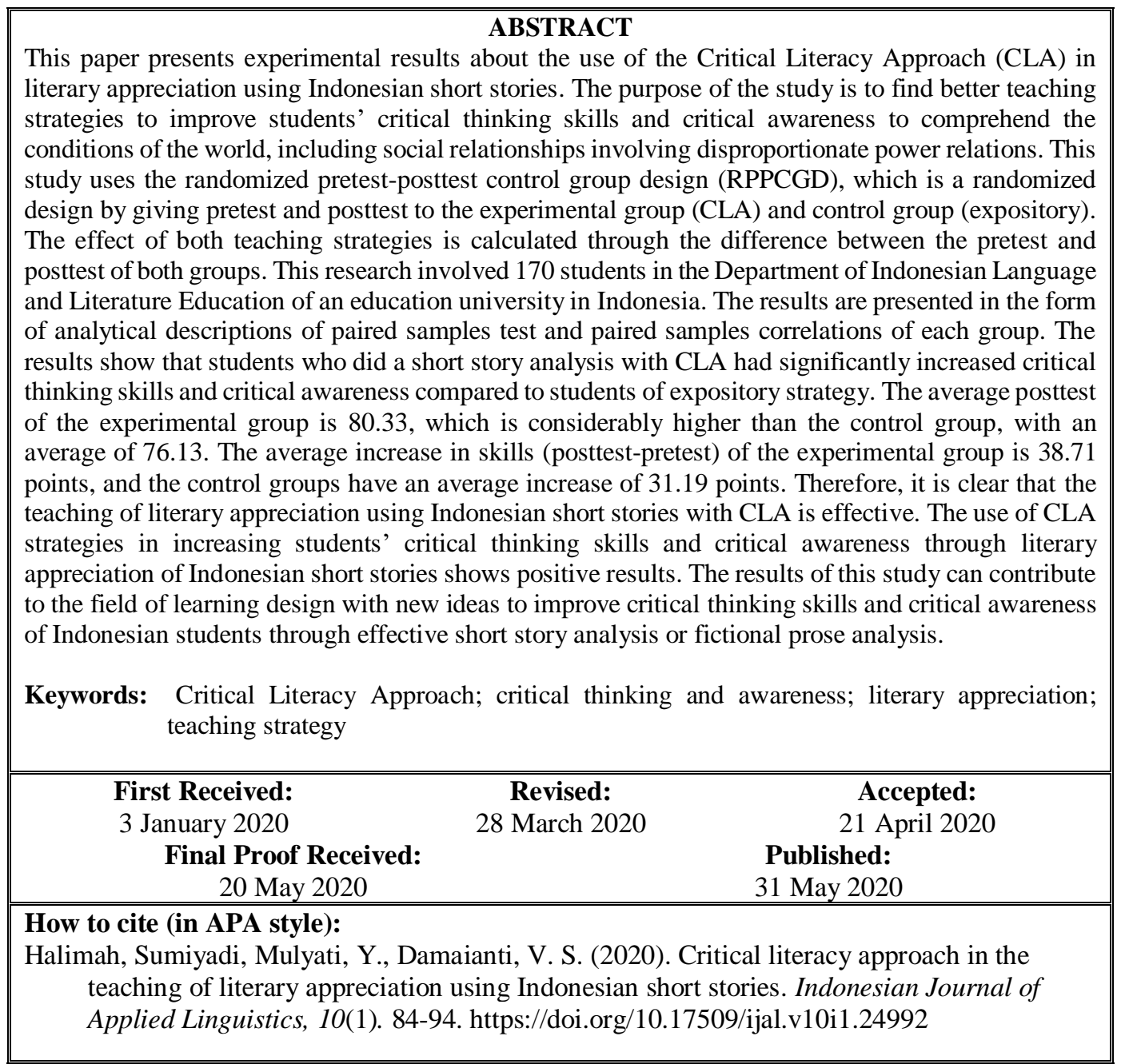

\section{INTRODUCTION}

Critical thinking is essential in social life for it has an impact on positive changes in the social fabric of society. Therefore, various efforts are needed in order to build and train critical thinking skills, one of them is by learning critical literacy. Critical Literacy Approach can be applied in various fields, especially in the field of literature. Priyatni (2012) stated that reading literature with a CLA is aimed to uncover the role of the practice of discourse to preserve the social world, including social relations involving disproportionate power relations.
Hendriani, (2018) explains that the history of critical literacy begins with Freire's thought, a pedagogist from Brazil who brought many changes to the world of education through his thoughts on the concept of literacy as an activity of reading words and the world. Freire (1997) explains that critical awareness is a concept of a step towards the achievement of praxis or critical reflection on the world and actions to change it. Hendriani (2018) elaborated Gramsci's idea that critical literacy is considered a social skill. Ajayi's (2015) research presented that the application of multimodal critical

\footnotetext{
* Corresponding Author

Email: halimah_81@upi.edu
} 
literacy teaching to English language lessons for female students in Nigeria had an excellent impact on efforts to struggle for the emancipation of women.

CLA can be applied in various fields, including literature. In the field of Indonesian literature, it can be acquired through the learning of Indonesian short stories. In short stories, there are many meanings and purposes conveyed by the author to the reader such as self-depiction, socio-cultural, political, legal, historical, and many others. Rampan (2009) stated that short stories generally contain moral messages because literary writers, in general, have a moral responsibility to society, the state, and God.

The study of literary works needs to be realized as one aspect of critical thinking in the appreciation of literature. The potential of short stories can be explored from three different perspectives; to act as an intermediary on teaching people to read and write better, to continue community-based literacy programs as critical literacy practices, and to present an alternative and place for conflicting cultural forms (Trudgill, 1983; Gaber-Katz, 1996). Critical literacy is aimed to uncover aspects of the critical thinking process in understanding literary works.

In their study, Gustine and Insani (2019) found that four critical literacy resource models, to some extent, help students become critically aware especially at the stage of making meaning and criticizing text. Based on the results of the study, it is necessary to develop studies that have significance to enrich critical pedagogics in the scope of literacy education at the level of basic up to tertiary education. Another study was carried out by Tungka (2018) that discussed students' literacy in using the text features of web pages and navigating text while reading.

This paper is a continuation of research from existing studies. The fundamental difference in this research is to prioritize critical literacy as an approach to teaching literary appreciation by using short stories in higher education. Thus, it is expected to increase the in-depth understanding of the CLA as one of the techniques of teaching literary appreciation as well as increasing students' critical thinking skills on the phenomenon of social inequality presented through Indonesian short stories.

\section{Critical literacy}

Critical literacy is learning to read and write as part of the process of becoming aware through historical experience as constructed in certain power relations to take action and promote social justice (Anderson \& Irvine, 1993; Lee, 2020). Critical literacy is also a place for reading into words and worlds relating to power, identity, differences in accessing knowledge, skills, tools, and resources (Freire \& Macedo, 1987; Janks, 2013). Correspondingly, critical literacy allows for a more accurate understanding of the world, so that people can enter the "rewrite" world into a formation where their legitimate interests, identities, and aspirations are present to challenge the disproportionate power relations (Lankshear \& McLaren, 1993; Anderson \& Irvine, 1993).

Priyatni (2012) explained that critical literacy is closely related to critical thinking and critical awareness. Furthermore, critical thinking allows someone to think divergently, develop problemsolving skills, and develop thinking skills concerning cause and effect, perspectives/points of view, evidence, possibilities, and debate. Gunawan (2003) stated that critical thinking skills are the skills to think at a complex level using a process of analysis and evaluation. The identification of critical thinking must be accompanied by reasoning, argumentation, and emotion (Lipman, 2003; Rahim \& Chun, 2017; Shaari \& Hamzah, 2018). Critical thinking is closely related to critical reasoning. Albert (2014) stated that critical reasoning is carried out based on a critical assessment of the problems with strong facts in public awareness and social conditions. The aim is to produce critical arguments and critical lights in various fields.

Critical awareness involves deepening people's perceptions and perspectives and examining how our own biases, cultural assumptions, and world views influence the way we see power differences and dynamics (Sakamoto \& Pitner, 2005; Marlowe et al., 2015; Pérez, Guerrero, \& Mora, 2016). According to Priyatni (2012), critical awareness is a means to make someone more aware of the history, social, culture, and ideology that shape something and decide its' acceptance in a particular society. Lukacs (1967) suggested the concept of critical awareness as an ongoing awareness of rolling out the objectives that shape human life. Understanding the process of developing critical awareness encourages students to make the necessary connections between experience, related knowledge gained from that experience, and how to critically reflect on their' use of self' in an action (Higgins, 2011; Marlowe et al., 2015). The main component of critical awareness is staying aware of the interactions of one's social background and cultural experience accompanied by the supervision of someone considered an expert (Davys \& Beddoe, 2009; Marlowe et al., 2015).

Furlong and Wight (2011) cited two reasons for choosing critical awareness. The first one is critical awareness attitude that encourages practitioners to work with the principles of "curiosity" and "information that is informed without being known". The second one is that this orientation forms the context for practices that regard 'others' as a mirror through which practitioners can see the outline of their own personal, professional, ideological, and cultural profiles.

In practice, CLA can be done by understanding literary texts and discovering language patterns that voice specific ideas about power and oppression, whether based on race, social class, gender, or a combination of the three (Priyatni, 2012). 


\section{Literary appreciation}

Saryono (2009) explains that literary appreciation is the process (activity) of adornment, enjoyment, inspiration, and appreciation of literary works. Whether they are individual and momentary literary works, subjective and existential, spiritual and benevolent, solemn and whole, or intensive and total. This process is done for us to obtain something from literary works so that care, sensitivity, awareness, love, and involvement are values that we gain from them.

Literary appreciation activities can be carried out directly or indirectly. Aminuddin (2011) described direct literary appreciation as an activity of reading or enjoying literary inventions in the form of text or performance. This activity can be done in the form of reading, understanding, enjoying, and evaluating literary texts such as short stories, novels, romances, drama scripts, and poems. While indirect literary appreciation can be pursued by studying literary theory, reading articles related to literature, studying books and essays that discuss and provide an assessment of a literary work and studying the history of literature.

\section{Short story appreciation}

Abrams (2009) explained the term short story as a short work of fictional prose, and most of the terms for analyzing the components, types, and narrative techniques of novels also apply to short stories. Short stories are different from anecdotes which only describe a single event. Similar to novels, short stories organize the actions, thoughts, and dialogues of their characters into artful plot patterns.

Stanton (2007) stated that short stories are only equipped with limited details. They do not explain the character development of each character, relationships between characters, complex social circumstances, and/or events that take place over a long period at length. Furthermore, Stanton (2007) also stated that the style of short stories is compact, composed of various styles of levels, and changing the sensitivity of the reader's realism, understanding, emotions, and moral sensitivity simultaneously.

\section{Learning model of literary appreciation using indonesian short stories with CLA}

As Priyatni (2012) proposed, the learning model of fictional prose appreciation with CLA is carried out with the following steps. First, select a short story that voice ideas about power based on gender bias, race, social marginalization, exploitation, or powerlessness. Second, read the selected short story carefully, try to understand its contents, and find linguistics patterns that voice ideas about power. Try to explore various critical thoughts and critical awareness of the material and messages in the short story. For example, a bias that reflects the relationship between power in one group and oppression in another.

\section{METHOD}

This study used the randomized pretest-posttest control group design (RPPCGD), which was a randomized design by giving pretest and posttest to experimental group and control group in the form of tests to appreciate Seno Gumira Ajidarma's (2014) book of short stories collection Senja dan cinta yang berdarah (Bloody twilight and love) with five short stories analyzed from it, namely Gerobak (wagon), Tobong kobong (Fire pit), Penari dari Kunai (The dancer of Kunai), Si Kupu-kupu (The butterfly), and Maria. The effect of both teaching strategies was calculated through the difference between the pretest and posttest of both groups.

The difference between the experimental group and the control group was that the former received teaching with the CLA while the latter received expository strategy. The Expository strategy for the control group was chosen on the grounds that this strategy is commonly used in teaching literary appreciation by using short stories. In addition, expository strategy is sufficient to make students critical due to discussion and assignment sessions. The expected critical attitude is not much different from that of the CLA. The fundamental difference is that the delivery of material in the expository strategy is still done through lectures, while CLA is done directly through the exercise activities by prioritizing critical ideas which were built through short stories containing critical ideas.

\section{Teaching steps with CLA strategies (experimental group) \\ Assignment (Week 1)}

1. Students searched for short stories that voice critical thoughts and critical awareness concerning power, whether based on gender bias, race, social marginalization, exploitation, or powerlessness (from Indonesian short stories).

2. Short stories searching was done by reading a book of short stories or searching on the internet.

3. Students read theories about language and power that could support the discussion related to the short stories that had been found.

4. Students analyzed examples of short story appreciation that expressed ideas about power, whether based on gender bias, race, social marginalization, exploitation, or powerlessness.

Assignment (Week 2)

1. 85 experimental group students were divided into five large groups of 17 members each.

2. 17 students in each group analyzed the same short story but did so individually.

3. The lecturer chose 5 Indonesian short stories filled with critical literacy content for 5 large groups.

4. Each student read a chosen short story. 
5. Students discussed the linguistic patterns that could be used to conclude that the short stories they read voiced ideas about power.

6. Each student was assigned a short story from the short stories that were found to be discussed further.

7. Lecturer gave assignments (pretest) for each student to analyze the assigned short story at home (collected at the next meeting).

Assignment (Week 3)

1. Lecturer collected the assignments (pretest) of short story analysis.

2. Each student re-read intensely the previously assigned short story.

3. Each student analyzed the structure of the short story they read.

4. Each student marked the paragraphs of the short story that contain ideas about power.

5. Students discussed ideas about power that were contained in the short stories.

6. Students connected their analysis with theories of power.

7. Students compiled their analysis in the form of essays.

8. Students edited the essays they wrote.

Meetings (Week 4 to week 7)

1. Each student presented his/her essay in class discussions.

2. Lecturer and students gave feedbacks on the essays and presentations.

3. Lecturer gave rectifications.

4. Meeting week 7, lecturer gave assignments to revise the short story analysis (posttest).

\section{Teaching steps with expository strategies (control group)}

The activities of fictional prose appreciation using Expository strategies were carried out in 7 meetings with the same stages in each meeting. The steps of fictional prose appreciation were presented at each meeting.

The stages of Expository strategy in fictional prose appreciation were as follows.

1. In the preparation stage, the lecturer formulated the objectives and subject matter clearly and measurably.

2. In the preliminary stage, the lecturer conveyed the main points of the subject to be discussed and the objectives to be achieved; students followed by taking notes if necessary.

3. In the presentation stage of the subject, the lecturer presented the subject matter with a lecture, then proceeded with the presentation of the analysis examples.

4. In the process of teaching activities, lecturer functioned as a source of messages and students functioned as the recipients of messages. Lecturers used question and answer techniques as a process of interaction in the class.

5. In the closing stage, the lecturer carried out follow-up activities in the form of assignments for an in-depth understanding of the subject. Expository strategy process was expected to encourage students to want to learn the subject matter further.

6. At the second week's meeting, the lecturer chose 5 short stories filled with critical literacy contents. Each student was assigned one short story to discuss further. The lecturer made 5 large groups of 17 people and each group discussed 1 different short story. Short story analysis was done by all group members (analysis was done by each student individually). Lecturer gave assignments (pretest).

From the 4th to 7th week, the students presented the results of their short story analysis. At the 7th week meeting, the lecturer gave the assignment to improve the analysis of the short stories that had been done before (posttest).

\section{Assessment}

Table 1 shows the assessment parameters of CLA to short story.

\section{Experimental procedure}

As shown in Figure 1, both the experimental and control group consisted of 85 people each. Both groups were then divided into 5 large groups of 17 people and each group analyzed the same short story.

Then the same N.Gain values of each group were compared to obtain the research conclusions.

\section{Population and research samples}

The population is the whole unit (people, groups, institutions, regions, etc.) that are the objects of research (Siegel, 1988). The population of this study was 170 student participants of the Department of Indonesian Language and Literature Education of an education university in West Java, Indonesia, in an Indonesian fictional prose appreciation course.

The research sample was 85 people in experimental group and 85 people in control group who analyzed 5 Indonesian short stories by Ajidarma (2014). Experimental group 1 and control group 1 appreciated the short story "Gerobak" (Wagon); Experimental group 2 and control group 2 appreciated the short story "Tobong Kobong" (Fire pit); Experimental group 3 and control group 3 appreciated the short story "Penari dari Kunai" (The dancer of Kunai); Experimental group 4 and control group 4 appreciated the short story "Si Кири-kupu" (The Butterfly); Experimental group 5 and control 
Table 1

Assessment Parameters of CLA to Short Story (adapted from Priyatni, 2012; Nurgiyantoro, 1988)

\begin{tabular}{llll}
\hline $\begin{array}{l}\text { Aspects of } \\
\text { assessment }\end{array}$ & Score & Classification & Decriptions \\
\hline $\begin{array}{l}\text { Quality of Content } \\
\text { (40 points) }\end{array}$ & $31-40$ & Excellent & $\begin{array}{l}\text { The analysis is done perfectly, completely, and profoundly. It uses } \\
\text { appropriate analytical theory and analyzes ideas about critical thinking } \\
\text { and critical awareness concerning power based on gender bias, race, }\end{array}$ \\
& & $\begin{array}{l}\text { social marginalization, exploitation, or helpless in depth. The } \\
\text { appreciation is collaboratively packed covering theory, logic, and } \\
\text { includes passages from the short story as empirical evidence. }\end{array}$
\end{tabular}

21-30 Good The analysis is done close to perfectly, completely, and profoundly. It uses the right analytical theory and raises more than two ideas. The appreciation is collaboratively packed covering theory, logic, and includes passages from the short story as empirical evidence.

11-20 Average The analysis is done well, adequately, and quite profoundly. It raises only two ideas. The appreciation covers theory, logic, and includes passages from the short story as empirical evidence but not collaboratively well and shows yet complete analysis.

1-10 Poor The analysis is incomplete and lacking profoundness. It only raises one idea power based on gender bias, race, social marginalization, exploitation, or helplessness. The analysis does not cover enough theory of appreciation, logic, and does not include enough passages from the short story as empirical evidence.

$\begin{array}{llll}\text { Organization and } & 16-20 & \text { Excellent } & \text { The analysis contains a complete structure. It contains a very good } \\ \text { Presentation of } & & & \begin{array}{l}\text { opening paragraph, displays the contents very well, is cohesive and } \\ \text { coherent across paragraphs, and contains a very good closing } \\ \text { paragraph. }\end{array}\end{array}$

11-15 Good The analysis contains a complete structure. It contains a good opening paragraph, displays the contents well, is cohesive and coherent across paragraphs, and contains a good closing paragraph.

\begin{tabular}{|c|c|c|c|}
\hline & $6-10$ & Average & $\begin{array}{l}\text { The analysis goes straight to illustrate the content but contains fairly } \\
\text { good cohesion and coherence. }\end{array}$ \\
\hline & $1-5$ & Poor & $\begin{array}{l}\text { The analysis goes straight to illustrate the content but lacks good } \\
\text { cohesion and coherence. }\end{array}$ \\
\hline \multirow[t]{4}{*}{$\begin{array}{l}\text { Diction/Word Choice } \\
\text { (20 points) }\end{array}$} & $16-20$ & Excellent & $\begin{array}{l}\text { The analysis uses appropriate diction, hence produces a lively, flowing, } \\
\text { clear, and complete analysis. }\end{array}$ \\
\hline & $11-15$ & Good & $\begin{array}{l}\text { The analysis uses good diction, hence produces a flowing, clear, and } \\
\text { complete analysis. }\end{array}$ \\
\hline & $6-10$ & Average & $\begin{array}{l}\text { The analysis uses fairly good diction but produces less than flowing, } \\
\text { clear, and complete analysis. }\end{array}$ \\
\hline & $1-5$ & Poor & $\begin{array}{l}\text { The analysis uses less proper diction, hence produces a less than } \\
\text { flowing, clear, and complete analysis }\end{array}$ \\
\hline \multirow{4}{*}{$\begin{array}{l}\text { Spelling } \\
\text { (20 points) }\end{array}$} & $16-20$ & Excellent & Spelling is in accordance with the predetermined rules \\
\hline & $11-15$ & Good & $\begin{array}{l}\text { More than half of the spelling is in accordance with the predetermined } \\
\text { rules }\end{array}$ \\
\hline & $6-10$ & Average & Half of the spelling is in accordance with the predetermined rules \\
\hline & $1-5$ & Poor & $\begin{array}{l}\text { More than half of the spelling is not in accordance with the } \\
\text { predetermined rules }\end{array}$ \\
\hline
\end{tabular}

group 5 appreciated the short story "Maria". Seno Gumira Ajidarma is a popular Indonesian writer since the 1970s. Ajidarma had been the most prolific short story writer in the period of 1970-2018. Ajidarma's short stories express many critical ideas in the form of social issues, gender bias, economic problems and others. For example, the short story "Gerobak" raises socio-economic issues in poor countries. "Tobong Kobong", "Penari dari Kutai", "Si Kupu-kupu" and "Maria" raise the theme of gender bias, exploitation of women, and social and cultural issues of society. 
Figure 1

Experimental Research Procedure Diagram

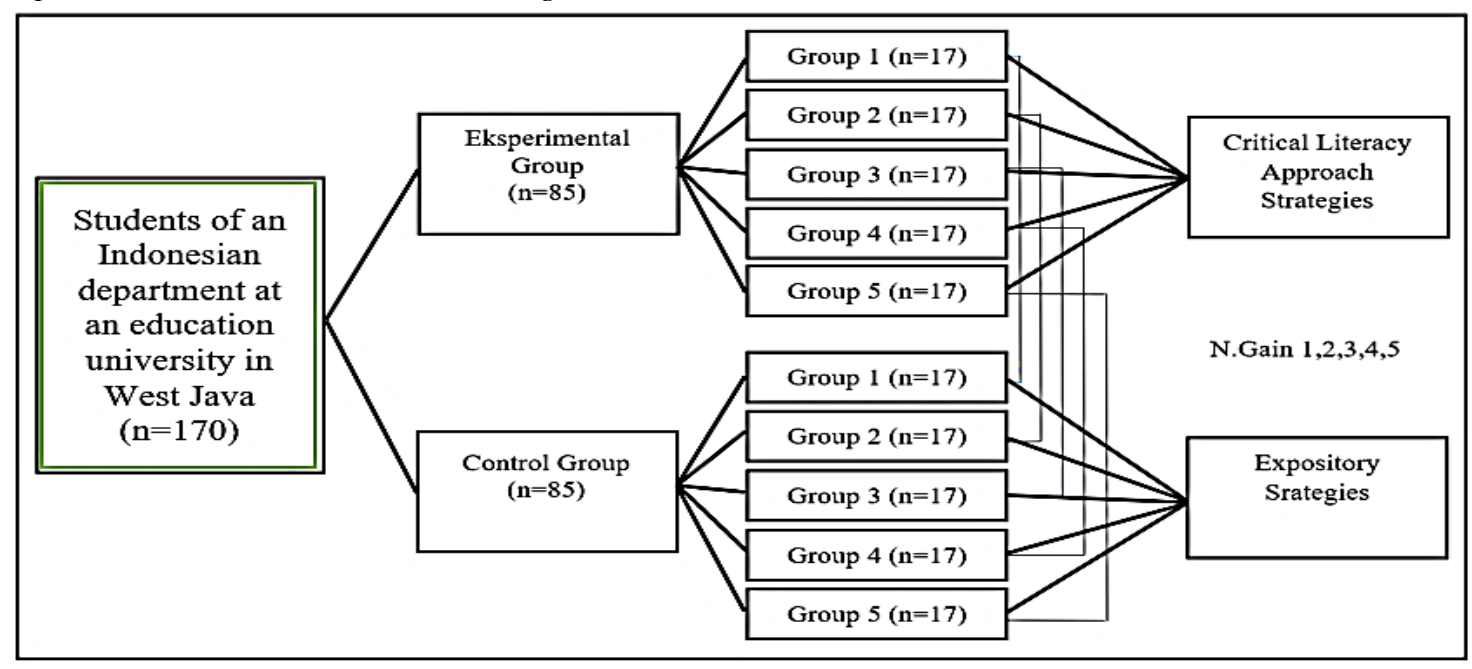

\section{Data collection technique}

In this study, the researchers used two data collection techniques, namely tests and literature study. The test technique was used to determine the outcomes of the pretest and posttest conducted on the experimental and control groups. Literature study was used as the basis for the underlying theory.

The study was conducted to observe the quality of conducting literary appreciation lectures with CLA. The type of observation used in this study was participatory observation, in which the observer performed two roles at once namely as an observer and as a co-lecturer.

\section{RESULTS}

The results of this study provide a comparative picture of the literary appreciation skills of experimental and control group students.

Comparison of the increase in skills of Indonesian short stories appreciation between CLA group and expository strategy group

\section{Normality Test}

Table 2 displays tabulation of the normality test results of this study.

In Table 2, it can be seen that the results of the normality test of the students' short story analysis skills, based on the Kolmogorov-Smirnov, of the experimental group shows the value of sig. $0.090>\alpha$ (0.05) which means that the data were normally distributed.

\section{Homogeneity Test}

Table 3 shows the Homogeneity test results of this study. The test results indicate that the value of sig. $0.545>\alpha(0.05)$, meaning that the sample is from a homogeneous population.
Table 2

Normality Test

\begin{tabular}{lrllrrr}
\hline & \multicolumn{3}{c}{$\begin{array}{c}\text { Kolmogorov- } \\
\text { Smirnova }\end{array}$} & \multicolumn{3}{c}{ Shapiro-Wilk } \\
\cline { 2 - 7 } & Statistic & df & Sig. & Statistic & df & Sig. \\
\hline Experiment_CLA & .089 & 85 & .090 & .970 & 85 & .042 \\
Control_expository & .066 & 85 & $.200^{*}$ & .974 & 85 & .085 \\
\hline
\end{tabular}

*. This is a lower bound of the true significance.

a. Lilliefors significance correction

Table 3

Homogeneity Test of Variances

\begin{tabular}{rccc}
\hline Levene Statistic & df1 & df2 & Sig. \\
\hline .368 & 1 & 168 & .545 \\
\hline
\end{tabular}

Comparison of the increase in skills of analyzing the short story "Gerobak" between experimental group 1 and control group 1

The pretest and posttest results of the experimental group 1 and control group 1 who analyzed the short story "Gerobak" is shown in Table 4. The experimental group 1 has the value of $\mathrm{t}=-26.034$, with $p$-value (2-tailed) much smaller than 0.05 . The control group 1 has the value of $t=-14.807$ much smaller than 0.05 . Therefore, it can be said that there is an increase in short story analysis skill of both the experimental and control group.

Table 5 shows that the correlation value between the pretest-posttest scores of the experimental group 1 is positive at 0.707 and categorized as strong. The correlation value of the control group 1 is 0.387 and categorized as Low.

The skills of short story analysis of experimental group 1 and control group 1 increased after using both the CLA and Expository strategy. However, the increase in students' skills of short story analysis tends to be better with the former. 
Comparison of the increase in skills of analyzing the short story "Tobong Kobong" between Experimental group 2 and control group 2

The pretest and posttest results of the experimental group 2 and control group 2 who analyzed the short story "Tobong Kobong" is shown in Table 6.

Experimental group 2 has the value of $\mathrm{t}=$ 17.249, df $=16$, with $p$-value (2-tailed) much smaller than 0.05 . The control group 2 has the value of $\mathrm{t}=-13.239 \mathrm{df}=16$, with $p$-value (2-tailed) much smaller than 0.05 . Therefore, it can be said that there is an increase in short story analysis skill of both the experimental and control group.

Table 7 shows that the correlation value between the pretest-posttest scores of the experimental group 2 is positive at 0.458 and categorized as Average. The correlation value of the control group 2 is 0.304 and categorized as Low.

Table 4

Paired Sample Test of Groups 1

\begin{tabular}{|c|c|c|c|c|c|c|c|c|c|}
\hline \multicolumn{10}{|c|}{ erences } \\
\hline & & \multirow[t]{2}{*}{ Mean } & \multirow{2}{*}{$\begin{array}{c}\text { Std. } \\
\text { Deviation }\end{array}$} & \multirow{2}{*}{$\begin{array}{l}\text { Std. } \\
\text { Error } \\
\text { Mean }\end{array}$} & \multicolumn{2}{|c|}{$\begin{array}{l}\text { 95\% Confidence Interval } \\
\text { of the Difference }\end{array}$} & \multirow[t]{2}{*}{$\mathbf{t}$} & \multirow[t]{2}{*}{ df } & \multirow[t]{2}{*}{$\begin{array}{l}\text { Sig. (2- } \\
\text { tailed) }\end{array}$} \\
\hline & & & & & Lower & Upper & & & \\
\hline Pair 1 & $\begin{array}{l}\text { Pre_Test_Ex1 - } \\
\text { Post_Test_Ex1 }\end{array}$ & -38.412 & 6.083 & 1.475 & -41.540 & -35.284 & -26.034 & 16 & .000 \\
\hline Pair 2 & $\begin{array}{l}\text { Pre_Test_C1 - } \\
\text { Post_Test_C1 }\end{array}$ & -32.118 & 8.943 & 2.169 & -36.716 & -27.519 & -14.807 & 16 & .000 \\
\hline
\end{tabular}

Table 5

Paired Sample Correlations of Groups 1

\begin{tabular}{llccc}
\hline & & N & Correlation & Sig. \\
\hline \multirow{2}{*}{ Pair 1 } & $\begin{array}{l}\text { Pre_Test_Ex1 \& } \\
\text { Post_Test_Ex1 }\end{array}$ & 17 & .707 & .002 \\
\hline \multirow{2}{*}{ Pair 2 } & $\begin{array}{l}\text { Pre_Test_C1 \& } \\
\text { Post_Test_C1 }\end{array}$ & 17 & .387 & .125 \\
\hline
\end{tabular}

Table 6

Paired Sample Test of Groups 2

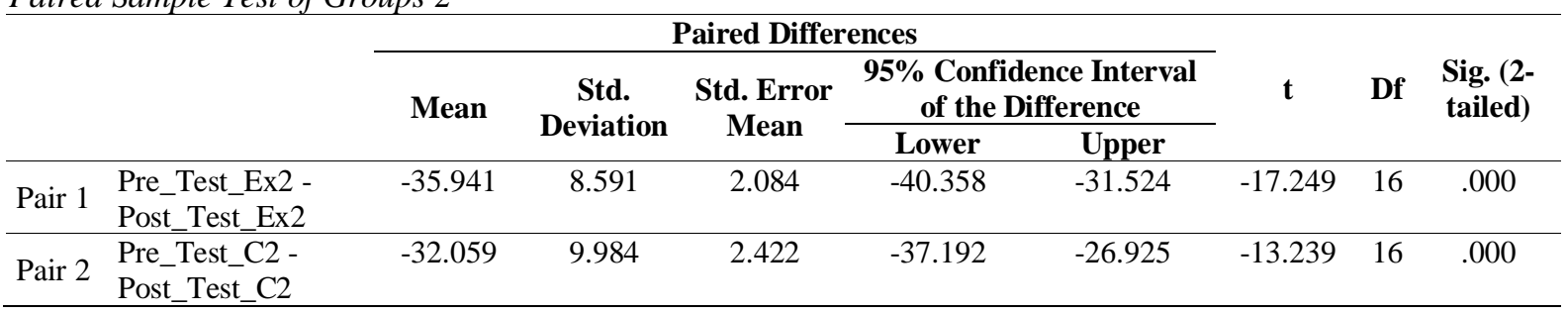

Table 7

Paired Sample Correlations of Groups 2

\begin{tabular}{llrrr}
\hline & & N & Correlation & Sig. \\
\hline \multirow{2}{*}{ Pair 1 } & $\begin{array}{l}\text { Pre_Test_Ex2 \& } \\
\text { Post_Test_Ex2 }\end{array}$ & 17 & .458 & .065 \\
\hline \multirow{2}{*}{ Pair 2 } & $\begin{array}{l}\text { Pre_Test_C2 \& } \\
\text { Post_Test_C2 }\end{array}$ & 17 & .304 & .235 \\
\hline
\end{tabular}

The skills of short story analysis of experimental group 2 and control group 2 increased after using both the CLA and Expository strategy. However, the increase in students' skills of short story analysis tends to be better with the former.

Table 8

Paired Sample Test of Groups 3

\begin{tabular}{|c|c|c|c|c|c|c|c|c|c|}
\hline & & \multicolumn{5}{|c|}{ Paired Differences } & \multirow{3}{*}{$\mathbf{t}$} & \multirow{3}{*}{ df } & \multirow{3}{*}{$\begin{array}{l}\text { Sig. (2- } \\
\text { tailed) }\end{array}$} \\
\hline & & \multirow[t]{2}{*}{ Mean } & \multirow{2}{*}{$\begin{array}{c}\text { Std. } \\
\text { Deviation }\end{array}$} & \multirow{2}{*}{$\begin{array}{c}\text { Std. Error } \\
\text { Mean }\end{array}$} & \multicolumn{2}{|c|}{$\begin{array}{l}\text { 95\% Confidence Interval } \\
\text { of the Difference }\end{array}$} & & & \\
\hline & & & & & Lower & Upper & & & \\
\hline Pair 1 & $\begin{array}{l}\text { Pre_Test_Ex3 - } \\
\text { Post_Test_Ex3 }\end{array}$ & -42.000 & 6.010 & 1.458 & -45.090 & -38.910 & -28.812 & 16 & .000 \\
\hline Pair 2 & $\begin{array}{l}\text { Pre_Test_C3 - } \\
\text { Post_Test_C3 }\end{array}$ & -29.706 & 6.546 & 1.588 & -33.071 & -26.340 & -18.712 & 16 & .000 \\
\hline
\end{tabular}

Comparison of the increase in skills of analyzing the short story "Penari dari Kutai" between experimental group 3 and control group 3

The pretest and posttest results of the experimental group 3 and control group 3 who analyzed the short story "Penari dari Kutai" is shown in Table 8.

The experimental group 3 has the value of $\mathrm{t}=$ 28.812, df $=16$, with $p$-value (2-tailed) much smaller than 0.05 . The control group 3 has the value of $\mathrm{t}=-18.712 \mathrm{df}=16$, with $p$-value (2-tailed) much smaller than 0.05 . Therefore, it can be said that there is an increase in short story analysis skill of both the experimental and control group. 
Table 9 shows that the correlation value between the pretest-posttest scores of the experimental group 3 is positive at 0.712 and categorized as Strong. The correlation value of the control group 3 is 0.614 and categorized as Strong.

Table 9

Paired Samples Correlation of Groups 3

\begin{tabular}{|c|c|c|c|c|}
\hline & & $\mathbf{N}$ & Correlation & Sig. \\
\hline Pair 1 & $\begin{array}{l}\text { Pre_Test_Ex3 \& } \\
\text { Post Test_Ex3 }\end{array}$ & 17 & .712 & .001 \\
\hline Pair 2 & $\begin{array}{l}\text { Pre_Test_C3 \& } \\
\text { Post_Test_C3 }\end{array}$ & 17 & .614 & .009 \\
\hline
\end{tabular}

Therefore, the skills of short story analysis of experimental group 3 and control group 3 increased after using both the CLA and Expository strategy. However, the increase in students' skills of short story analysis tends to be better with the former.

Comparison of the increase in skills of analyzing the short story "Si Kupu-kupu" between experimental group 4 and control group 4

The pretest and posttest results of the experimental group 4 and control group 4 who analyzed the short story "Si Kupu-kupu” is shown in Table 10.

Table 10

Paired Samples Test of Groups 4

\begin{tabular}{|c|c|c|c|c|c|c|c|c|c|}
\hline & & \multirow{3}{*}{ Mean } & \multicolumn{4}{|c|}{ Paired Differences } & \multirow{3}{*}{$\mathbf{t}$} & \multirow{3}{*}{ df } & \multirow{3}{*}{$\begin{array}{l}\text { Sig. }(2- \\
\text { tailed) }\end{array}$} \\
\hline & & & \multirow{2}{*}{$\begin{array}{c}\text { Std. } \\
\text { Deviation }\end{array}$} & \multirow{2}{*}{$\begin{array}{l}\text { Std. Error } \\
\text { Mean }\end{array}$} & \multicolumn{2}{|c|}{$\begin{array}{l}95 \% \text { Confidence Interval } \\
\text { of the Difference }\end{array}$} & & & \\
\hline & & & & & Lower & Upper & & & \\
\hline Pair 1 & $\begin{array}{l}\text { Pre_Test_Ex4 - } \\
\text { Post_Test_Ex4 }\end{array}$ & -40.706 & 4.120 & .999 & -42.824 & -38.588 & -40.741 & 16 & .000 \\
\hline Pair 2 & $\begin{array}{l}\text { Pre_Test_C4 - } \\
\text { Post_Test_C4 }\end{array}$ & -31.294 & 10.233 & 2.482 & -36.556 & -26.033 & -12.609 & 16 & .000 \\
\hline
\end{tabular}

The experimental group 4 (CLA) has the value of $\mathrm{t}=-40.741, \mathrm{df}=16$, with $p$-value (2-tailed) much smaller than 0.05 . The control group 4 (expository) has the value of $\mathrm{t}=-12.609 \mathrm{df}=16$, with $p$-value (2tailed) much smaller than 0.05 . Therefore, it can be said that there is an increase in short story analysis skill of both the experimental and control group.

Table 11 shows that the correlation value between the pretest-posttest scores of the experimental group 4 is positive at 0.867 and categorized as very strong. The correlation value of the control group 4 is 0.486 and categorized as average.

Table 11

Paired Samples Correlations of Groups 4

\begin{tabular}{|c|c|c|c|c|}
\hline & & $\mathbf{N}$ & Correlation & Sig. \\
\hline Pair 1 & $\begin{array}{l}\text { Pre_Test_Ex4 \& } \\
\text { Post_Test_Ex4 }\end{array}$ & 17 & .867 & .000 \\
\hline Pair 2 & $\begin{array}{l}\text { Pre_Test_C4 \& } \\
\text { Post_Test_C4 }\end{array}$ & 17 & .486 & .048 \\
\hline
\end{tabular}

The skills of short story analysis of experimental group 4 and control group 4 increased after using both the CLA and Expository strategy. However, the increase in students' skills of short story analysis tends to be better with the former.
Comparison of the increase in skills of analyzing the short story "Maria" between experimental group 5 and control group 5

The pretest and posttest of the results experimental group 4 and control group 4 who analyzed the short story "Maria" is shown in Table 12.

The experimental group 5 (CLA) has the value of $\mathrm{t}=-44.556, \mathrm{df}=16$, with $p$-value (2-tailed) much smaller than 0.05 . The control group 4 (expository) has the value of $\mathrm{t}=-19.442 \mathrm{df}=16$, with $p$-value (2tailed) much smaller than 0.05 . Therefore, it can be said that there is an increase in short story analysis skill of both the experimental and control group.

Table 13 shows that the correlation value between the pretest-posttest scores of the experimental group 5 is positive at 0.945 and as very strong. The correlation value of the control group 5 is 0.706 and categorized as Strong.

The skills of short story analysis of experimental group 5 and control group 5 increased after using both the CLA and Expository strategy. However, the increase in students' skills of short story analysis tends to be better with the former.

The overall comparison of each experimental and control group can be seen in Table 14 .

Table 12

Paired Samples Test of Groups 5

\begin{tabular}{|c|c|c|c|c|c|c|c|c|c|}
\hline & \multicolumn{5}{|c|}{ Paired Differences } & \multirow{3}{*}{$\mathbf{t}$} & \multirow{3}{*}{ df } & \multirow{3}{*}{$\begin{array}{l}\text { Sig. (2 } \\
\text { tailed) }\end{array}$} \\
\hline & & \multirow[t]{2}{*}{ Mean } & \multirow{2}{*}{$\begin{array}{c}\text { Std. } \\
\text { Deviation }\end{array}$} & \multirow{2}{*}{$\begin{array}{c}\text { Std. Error } \\
\text { Mean }\end{array}$} & \multicolumn{2}{|c|}{$\begin{array}{l}\text { 95\% Confidence Interval of } \\
\text { the Difference }\end{array}$} & & & \\
\hline & & & & & Lower & Upper & & & \\
\hline Pair 1 & $\begin{array}{l}\text { Pre_Test_Ex5 - } \\
\text { Post_Test_Ex5 }\end{array}$ & -36.471 & 3.375 & .819 & -38.206 & -34.735 & -44.556 & 16 & .000 \\
\hline Pair 2 & $\begin{array}{l}\text { Pre_Test_C5 - } \\
\text { Post_Test_C5 }\end{array}$ & -30.765 & 6.524 & 1.582 & -34.119 & -27.410 & -19.442 & 16 & .000 \\
\hline
\end{tabular}


Table 13

Paired Samples Correlations of Groups 5

\begin{tabular}{llccc}
\hline & & N & Correlation & Sig. \\
\hline Pair 1 & Pre_Test_Ex5 \& Post_Test_Ex5 & 17 & .945 & .000 \\
Pair 2 & Pre_Test_C5 \& Post_Test_C5 & 17 & .706 & .002 \\
\hline
\end{tabular}

Table 14

\begin{tabular}{|c|c|c|c|c|c|c|}
\hline Group & $\begin{array}{c}\text { Pretest } \\
\text { Average }\end{array}$ & $\begin{array}{l}\text { Posttest } \\
\text { Average }\end{array}$ & $\begin{array}{c}\text { Gain } \\
\text { Average }\end{array}$ & $\begin{array}{c}\text { Max-Ypre } \\
\text { Score Average }\end{array}$ & $\begin{array}{l}\text { N. Gain } \\
\text { Average }\end{array}$ & $\begin{array}{l}\text { N. Gain } \\
\text { Category }\end{array}$ \\
\hline $\begin{array}{l}\text { Experimental } 1(\mathrm{n}=17) \\
\text { Analyzing "Gerobak" }\end{array}$ & 39.82 & 78.24 & 38.41 & 60.18 & 0.64 & Average \\
\hline $\begin{array}{l}\text { Control } 1(\mathrm{n}=17) \\
\text { Analyzing "Gerobak" }\end{array}$ & 43.71 & 75.82 & 32.12 & 56.29 & 0.57 & Average \\
\hline $\begin{array}{l}\text { Experimental } 2(\mathrm{n}=17) \\
\text { Analyzing "Tobong Kobong" }\end{array}$ & 41.76 & 77.71 & 35.94 & 58.24 & 0.62 & Average \\
\hline $\begin{array}{l}\text { Control } 2(\mathrm{n}=17) \\
\text { Analyzing "Tobong Kobong" }\end{array}$ & 43.24 & 75.29 & 32.06 & 56.76 & 0.56 & Average \\
\hline $\begin{array}{l}\text { Experimental } 3(\mathrm{n}=17) \\
\text { Analyzing "Penari dari Kutai" }\end{array}$ & 39.82 & 81.82 & 42.00 & 60.18 & 0.70 & High \\
\hline $\begin{array}{l}\text { Control } 3(\mathrm{n}=17) \\
\text { Analyzing "Penari dari Kutai" }\end{array}$ & 44.53 & 74.24 & 29.71 & 55.47 & 0.54 & Average \\
\hline $\begin{array}{l}\text { Experimental } 4(\mathrm{n}=17) \\
\text { Analyzing "Si Kupu-kupu" }\end{array}$ & 41.76 & 82.47 & 40.71 & 58.24 & 0.71 & High \\
\hline $\begin{array}{l}\text { Control } 4(\mathrm{n}=17) \\
\text { Analyzing "Si Kupu-kupu" }\end{array}$ & 45.06 & 76.35 & 31.29 & 54.94 & 0.56 & Average \\
\hline $\begin{array}{l}\text { Experimental } 5(\mathrm{n}=17) \\
\text { Analyzing "Maria" }\end{array}$ & 44.94 & 81.41 & 36.47 & 55.06 & 0.67 & Average \\
\hline $\begin{array}{l}\text { Control } 5(\mathrm{n}=17) \\
\text { Analyzing "Maria" }\end{array}$ & 48.18 & 78.94 & 30.76 & 51.82 & 0.60 & Average \\
\hline
\end{tabular}

In conclusion, there is a difference in the increase of analytical skills between the experimental group and the control group. The experimental group tends to have a higher increase than the control group. Therefore, literary appreciation with CLA is effective.

\section{DISCUSSION}

This experimental research focused on the use of CLA in the teaching of literary appreciation. The research was conducted on students of the Indonesian Language and Literature Education Department. The findings revealed that students with CLA have better improved analytical skills than students with an expository teaching strategy. From the 5 experimental groups, it was proven that the improvement in the analytical skills of the experimental group students was better on average than the control group. Therefore, teaching literary appreciation with CLA was effective, because it provided a positive effect for students in improving their skills to analyze short stories. In addition to that, teaching with the CLA could improve critical thinking skills and critical awareness in responding to social symptoms both in short stories and in real life. However, this must also be supported by providing reading materials or texts. The easier the texts are understood then the more critical the students become (Setyaningsih, 2019).

This research is in line with the results of Ariyati's (2017) study that stated that CLA can positively influence the character formation of students. She suggested that critical literacy was not only about text selection but also about compiling questions critically to explore information in the text. Other positive influences of CLA towards characters formation include the emergence of enthusiasm, reason, respect for differences, argumentativeness, and critical thinking inspired by humanist values (Morais, 2017).

This research is also in line with Hendriani (2018) study which revealed that the application of critical literacy in social learning can provide broad insights and improve students' critical thinking skills in social phenomena. It also compels students to understand and know their role as modifiers of inadequate social reality and social inequality.

Minott's (2011) research in reflective teaching and critical literacy also revealed that there was involvement of careful consideration or thought to create meaning and provide judgment, question personal assumptions, values and beliefs, take initiative and use intuition, encourage and activate social change as well as utilizing journals as a medium for comparing different points of views from their readings. This shows that critical literacy directs students to explore ideas and create social changes.

Shah et al. (2012) suggested that critical literacy aims to develop analytical mindsets in an effort to mold mature attitudes for analyzing sociopolitical problems. Mature attitudes have a role in sociopolitical problems for exploring common perspective, having different perspectives, focusing on current social problems, and seeking to take action against oppression as well as assuming a role for 
social justice. CLA can help educators prepare the younger generation to ask critically, think critically, and dare to make decisions as a democratic society (Reidel \& Draper, 2011). This is an approach that builds the democratic attitude of students which is a way of creating patience among students and enabling them to make a room for others. Observing the critical literacy principle in class, there is an atmosphere where everyone is free to think, respond, and discuss their views on politics, religion, and so on.

Democratic attitudes that are built through CLA have a positive effect on the cognitive development of students and their sensitivity to good and bad values in the development of morality. This kind of teaching strategy needs to be developed and utilized in the field of education. This is in line with the opinion of Shaari and Hamzah (2018) who stated that the exploration of ways to develop thoughtful thinking in developing individual morality needs to be explored more deeply in the field of education.

\section{CONCLUSION}

This research discusses the differences in skills of the students of the Department of Indonesian Language and Literature Education in literary appreciation. Assessing the students using CLA improves their analytical and critical thinking skills. Furthermore, CLA also develops the students' character into individuals who have a mature attitude to analyze sociopolitical problems, and have social sensitivity to the phenomena of injustice and oppressions.

Literary appreciation is suitable as a teaching tool with a CLA. This is due to the fact that short stories present a variety of stories, various social conflict situations, politics, and also matters concerning issues of gender bias, race, social marginalization, exploitation, or powerlessness.

Teaching with CLA also needs to be developed in other fields of knowledge, especially with the development of an educational curriculum that aims to build moral and social characteristics of students.

This research on CLA showed significantly positive results. Thus, this study offers an effective teaching strategy for short story appreciation or fictional prose appreciation, which can be utilized as a teaching strategy in the educational environment both at the secondary and tertiary level.

What makes this research different from previous studies is that most of the previous studies focused on theoretical studies of critical literacy. However, this research is a theoretical application in literary appreciation. This research is also expected to help students' development which includes the betterment of several aspects such as knowledge, skills, and attitudes. Finally, the present study will also provide some in-depth information to curriculum designers and instructors.

\section{REFERENCES}

Abrams, M. H. (2009). A glossary of literary terms (9th ed). USA Wadsworth Cengage Learning.

Ajayi, L. (2015) Critical multimodal literacy: How Nigerian female students critique texts and reconstruct unequal social structures. Journal of Literacy Research, 47(2), 216-244. https://doi.org/10.1177\%2F1086296X1561847 8

Ajidarma, S. G. (2014). Senja dan cinta yang berdarah. PT. Kompas Media Nusantara.

Albert, H. (2014). Rekonstruksi nalar kritis: Revitalisasi ilmu kritis dalam wacana pruralisme teoretis. IRCiSoD.

Aminuddin. (2011). Pengantar apresiasi karya sastra. Sinar Baru Algensindo.

Anderson, G. L., \& Irvine, P. (1993). Informing critical literacy with ethnography. In C. Lankshear \& P. McLaren (Eds.). Critical literacy: Politics, praxis, and the postmodern (pp. 81-104). SUNY Press.

Ariyati, D. (2017). Pendidikan karakter melalui pembelajaran berbasis literasi kritis. Proceeding Seminar \#3: Bahasa dan Sastra Indonesia dalam Konteks Global (pp. 655662). Jember.

Davys, A. M., \& Beddoe, L. (2009). The reflective learning model: Supervision of social work students. Social Work Education, 28, 919-933. https://doi.org/10.1080/02615470902748662

Freire, P. (1997). Pedagogy of the oppressed (2nd Ed.). The Continuum Publishing Company.

Freire, P., \& Macedo, D. (1987). Literacy: Reading the word and the world. Bergin \& Garvey.

Furlong, M., \& Wight, J. (2011). Promoting "critical awareness" and critiquing "cultural competence" towards disrupting received professional knowledges. Australian Social Work, 64(1), 38-54. https://doi.org/10.1080/0312407X.2010.53735 2

Gaber-Katz, E. (1996). The use of story in critical literacy practice. Gender and Education, 8(1), 49-60. https://doi.org/10.1080/713668478

Gunawan, A. W. (2003). Genius learning strategy: Petunjuk praktis untuk menerapkan accelarated learning. Gramedia Pustaka Utama.

Gustine, G. G., \& Insani, H. N. (2019). English students' experience of reframing narrative stories from a critical literacy perspective. Indonesian Journal of Applied Linguistics, 8(3), 691-696. https://doi.org/10.17509/ijal.v8i3.15254

Hendriani, A. (2018). Pedagogik literasi kritis: Sejarah, filsafat dan perkembangannya di dunia pendidikan. Pedagogia: Jurnal Ilmu Pendidikan, 16(1), 44-59. https://doi.org/10.17509/pdgia.v16i1.10811 
Higgins, D. (2011). Why reflect? Recognizing the link between learning and reflection. Reflective Practice, 12(5), 583-584. https://doi.org/10.1080/14623943.2011.606693

Janks, H. (2013). Critical literacy in teaching and research. Education Inquiry, 4(2), 225-242. https://doi.org/10.3402/edui.v4i2.22071

Lankshear, C., \& McLaren, P. (1993). Preface. In C. Lankshear \& P. McLaren (Eds.), Critical literacy: Politics, praxis, and the postmodern (pp. xii-xx). SUNY Press.

Lee, C. G. (2020). Two plus four dimensions of critical literacy. Educational Philosophy and Theory, 52(1), 79-87. https://doi.org/10.1080/00131857.2019.160589 8

Lipman, M. (2003). Thinking in education. Cambridge University Press.

Lukacs, G. (1967). Theory, culture, and politics. Trancation Inc

Marlowe, J. M., Appleton, C., Chinnery, S., \& Stratum, S. V. (2015). The integration of personal and professional selves: Developing students' critical awareness in social work practice. Social Work Education: The International Journal, 34(1), 60-73. https://doi.org/10.1080/02615479.2014.949230

Minott, M. A. (2011). Reflective teaching, critical literacy and the teacher's tasks in the critical literacy classroom. A confirmatory investigation. Reflective Practice: International and Multidisciplinary Perspectives, 12(1), 7385. https://doi.org/10.1080/14623943.2011.541 096

Morais, J. (2017). Literacy and democracy. Language, Cognition and Neuroscience, 33(3), $351-$

372. https://doi.org/10.1080/23273798.2017.13 05116

Nurgiyantoro, B. (1988) Penilaian dalam pengajaran Bahasa dan Sastra Indonesia. BPFE.

Pérez, M. S., Guerrero, M. G. R., \& Mora, E. (2016). Black feminist photovoice: Fostering critical awareness of diverse families and communities in early childhood teacher education. Journal of Early Childhood Teacher Education, 37, 41-60. https://doi.org/10.1080/10901027.2015.113120 9

Priyatni, E. (2012). Membaca sastra dengan ancangan literasi kritis. Bumi Aksara.
Rahim, F. A., \& Chun, L. S. (2017). Proposing an affective literacy framework for young learners of English in Malaysian rural areas: Its key dimensions and challenges. Malaysian Journal of Learning and Instruction (MJLI), 14(2), 115-144. http://mjli.uum.edu.my/images/vol14no2dec17 /115-144cm.pdf

Rampan, K. L (2009). Apresiasi cerpen Indonesia mutakhir. Bukupop.

Reidel, M., \& Draper, C. A. (2011). Reading for democracy: Preparing middle-grades social studies teachers to teach critical literacy. The Social Studies, 102(3), 124131. https://doi.org/10.1080/00377996.2010.53 8758

Sakamoto, I., \& Pitner, R. (2005). Use of critical consciousness in anti-oppressive social work practice. British Journal of Social Work, 35, 435-452. https://doi.org/10.1093/bjsw/bch190

Saryono, D. (2009). Dasar apresiasi sastra. Elmatera Publishing.

Setyaningsih, E. (2019). Bringing critical literacy into tertiary EFL reading class. Indonesian Journal of Applied Linguistics, 9 (2) 297-307. https://doi.org/10.17509/ijal.v9i2.20220

Shaari, A., \& Hamzah, A. (2018). A comparative review of caring thinking and its implications on teaching and learning. Malaysian Journal of Learning and Instruction (MJLI), 15(1), 83104.

http://mjli.uum.edu.my/images/vol15New/BA

B4-A-COMPARATIVE-REVIEW-OF-

CARING-THINKING-AND-ITS-

IMPLICATIONS-ON-TEACHING-ANDLEARNING.pdf

Shah, K., Tabassum, R., Mahmood, R., \& Hussain, Q. (2012). Implications of critical literacy for language classroom. Journal of Education and Practice, 3(5), 31-39.

https://www.iiste.org/Journals/index.php/JEP/a rticle/view/1496/1428

Siegel, S., \& Castellan, N. J., Jr.

(1988). Nonparametric statistics for the behavioral sciences (2nd ed.). Mcgraw-Hill Book Company. Stanton, R. (2007). Teori fiksi Robert Stanton [Sugihastuti, Trans.]. Pustaka Pelajar.

Trudgill, P. (1983). Sociolinguistics: An introduction to language and society. Penguin.

Tungka, N. F. (2018). Guided literacy instruction: Helping students read multimodal Englishmedium texts. Indonesian Journal of Applied Linguistics, 8(2), 345-357. https://doi.org/10.17509/ijal.v8i2.13281 